\title{
Ecologically safe methods for presowing treatment of cereal seeds
}

\author{
V.V. Bezpal'ko ${ }^{1}$ L.V. Zhukova ${ }^{2}$, S.V. Stankevych ${ }^{2 *}$, Yu.H. Ogurtsov $^{3}$, I.I. Klymenko ${ }^{3}$, \\ R.A. Hutians'kyi ${ }^{3}$, A.M. Fesenko ${ }^{1}$, V.P. Turenko ${ }^{2}$, I.V. Zabrodina ${ }^{2}$, S.V. Bondarenko ${ }^{2}$, \\ O.M. Batova ${ }^{2}$, L.V. Golovan ${ }^{2}$, I.V. Klymenko3 ${ }^{3}$, A.A. Poedinceva ${ }^{2}$, V.O. Melenti ${ }^{2}$ \\ ${ }^{1}$ Petro Vasylenko Kharkiv National Technical University of Agriculture \\ Kharkiv, 61002, Ukraine \\ ${ }^{2}$ V.V. Dokuchaev Kharkiv National Agrarian University \\ v. Dokuchaevske, Kharkiv region, 62483, Ukraine \\ ${ }^{3}$ V. Ya. Yuryev Plant Production Institute of National Academy of Agrarian Science \\ Kharkiv, 61060, Ukraine \\ *Corresponding author. Tel.: +38-050-4000-985. E-mail: sergejstankevich1986@gmail.com
}

Received: 26.09.2019. Accepted: 26.10.2019

\begin{abstract}
We analyzed various sources of scientific literature and our data at the experimental field of the National Academy of Agrarian Sciences Plant Growing Institute named after V.Ya. Yuryev within 2010-2013. The irradiation of winter wheat and spring barley seeds with the electromagnetic fields of the extremely high frequencies (MWF of EHF) was carried out with the help of the equipment of the Kharkiv Technical University of Radio Electronics.

The treatment of seeds with the microwave oscillations of the extremely high frequency electromagnetic field (MWF of EHF) that is widely used for the operation of many radio and home microwave devices was done at the frequency range of $2.5-3.4 \mathrm{GHz}$, at the power of 0.9-1.8 kW for 5-95 seconds per $1 \mathrm{~kg}$ of seeds. The sowing quality of the seeds before and after treatment was determined in accordance with the current State Standard of Ukraine 4138-2002 in the laboratory of the seed production and seed science of the Plant Growing Institute named after V.Ya. Yuryev. The field experiments were performed in the crop rotation laboratory of the seed production and seed science. Pea for grain was sown before spring barley and the black fallow preceded winter wheat. During the experiments the area of the studied plot was $20 \mathrm{~m}^{2}$, the recurrence was four-times, and the placement of the plots were systemic.We suggested the optimum regimes of seeds irradiation with the microwave field of an extremely high frequency (MWF of EHF). They should be at range of 2.4-3.4 GHz with the power consumption of $0.9 \mathrm{~kW}$ per $1 \mathrm{~kg}$ of seed and at exposure of 45 seconds of $1.8 \mathrm{~kW}$ per $1 \mathrm{~kg}$ of seeds and exposure of 15-20 seconds. Such regimes cause the increased energy of germination, seeds sprouting, and crop capacity. We proposed to use this solution for improving and increasing the ecological features of winter wheat and spring barley by using the presowing microwave irradiation of seeds instead of chemical treatment. We considered the complex presowing treatment of seeds with MWF of EHF in combination with the plant growth regulators should be adopted and further enhanced.
\end{abstract}

Key words: Microwave field; Seed irradiation; Growth regulators; Efficiency; Winter wheat; Spring barley

\section{Introduction}

The world experience shows that in the countries with a high level of agro-technical support, the increase in the yield capacity of cereals reaches a critical point. The use of "intensive" technologies in the cultivation of agricultural crops since the 80's of the last century has led to an aggravation of contradictions between the economy and ecology. The intensive use of agricultural pesticides and mineral fertilizers, including chemical preparations for the presowing seeds treatment, increases the crops productivity, but at the same time, it inevitably causes a number of undesirable phenomena of the ecological and economic character.

One of the essential elements of the technological process in cultivating grain crops, which influences the increase in the crop capacity and quality of crop production, is the presowing treatment of seeds with the chemical and biological preparations of various origins. However, today the problems of seeds sanitation and the selection of the most viable biotypes with higher crop properties with the help of presowing treatment with ecologically safe methods have not been solved in Ukraine.

In recent years in order to reduce the negative agrochemicals influence on the environment, new alternative methods of seeds disinfection have been sought in Ukraine and abroad. Physical methods such as treatment with ozone, microwave and ultrasonic radiation, etc. are of a great interest (Tuchnyi, Karmazin, Dzyhovskyi, 2012; Tuchnyi, Karmazin, Levchenko, 2007; Tuchnyi and others 2007; Shevchenko et al., 2007).

One of the most ecologically safe and low-cost methods of presowing seeds treatment is the irradiation with a microwave field of an extremely high frequency (MWF of EHF). Along with the physical method of treatment the seed material with the microwave field the plant growth regulators and biological preparations, used to increase the plant resistance to the unfavourable factors and crop capacity of many agricultural plants, have become widespread in the agricultural practice (Lykhochvor, 2003; Anishyn, 2002). 
The history of the world agriculture development shows that fungal, bacterial and viral diseases, weeds, harmful insects and nematodes can dramatically reduce the gross production and quality of products, and in some cases they can completely destroy the crop. According to the data of FAO the world's losses of the basic crops yield due to the harmful organisms that cause the diseases amount to $21 \% ; 11 \%$ of the losses are caused by the pests and $24 \%$ of crop losses are due to the weeds (Sekun, 2007).

In Ukraine the average annual crop losses caused by the diseases, pests and weeds make up 20-30\%; the losses of wheat crop make up $27 \%$. Thus even partial loss prevention is an important factor which significantly increases the efficiency of crop production.

According to the data of the Institute of Plant Protection of the National Academy of Agrarian Sciences of Ukraine the fungi of the genus Alternaria, Fusarium, Drechslera, Bipolaris, Penicillium and others are present on the seeds (Yevtushenko, Mariutin, 2001). Very often two or more types of fungi are found on one seed, but the peculiarities of their development are quite different, therefore they do not allow introducing the thresholds of harmfulness (Horban, 2013; Spaar, 1996).

The phyto-sanitary situation is so unpredictable that leaving the seeds thrown into the soil without treatment, means to dismiss 60 $70 \%$ of the future harvest with a wave of your own hand. The most significant losses to the farmer are caused by the pathogenic organisms which can give rise to a number of plant diseases at the initial stage of their development and growth, first of all these diseases are bacterioses and mycoses ("Handbook ...", 1999).

For the first time the treatment of seeds (probably with sodium chloride) against the wheat Remnette described bunt in 1637. In 1733, Briton Tell recollected the treatment of cereal seeds with salty seawater. It happened by accident. In 1660, a ship with a cargo of wheat went down near Bristol. A portion of the grain was rescued, but it was not ground up into flour since it was saturated with salty water, so it was used as the seed material. Therefore, the peasants noticed an advantageous difference between "salty" and common crops (Fokin, 2009).

In addition to copper, mercury compounds and formaldehyde quite a large number of chemical compounds (acids, alkalis, salts of light and heavy metals, phenols, cresols, resins, organic paints, and substances that secrete an active chlorine) were used as seed treatment agents. On September 1, 1926, the German Plant Protection Service determined a list of 14 well-known trademarks that should be paid into attention. In general, the Germans have started such a "competition" since 1923. In its essence, it was the first recommended list of the seed treatment agents, the prototype of our domestic one "List ..." (Fokin, 2009).

Depending on the preparation, the biology of the disease pathogen, on the structure and other features of the seeds, the dry seeds, semidry, wet seeds and the seeds of moisture treatment are used in practice (Handbook ..., 1999).

The dry treatment consists of the even applying of dry powdery preparations on the surface of the seeds. The advantages of this method are the simplicity of the execution and the disadvantages are the low technical efficiency due to the weak sticking of the treatment agents to the seed and holding on it. This method is most ecologically dangerous and leads to the significant environmental pollution (Pryshchepa, 1998).

The semi-drying treatment consists of applying water suspensions or the treatment agents' solutions at a rate of 20-30 I $\mathrm{t}^{-1}$. on the surface of the seeds, followed by 3-4 hours of staining, ventilation and drying. The advantage of this method is a high efficiency of the infection elimination and the disadvantages are increasing of the moisture content in the seeds, a considerable labour-intensiveness and low productivity (Pryshchepa, 1998).

The wet treatment consists of the excessive moistening or soaking the seeds into the liquid (solution, suspension, or emulsion) treatment agent with the subsequent 2 hours staining, ventilation and drying. The advantage of this method is a high technical efficiency, and the disadvantages are the necessity for further drying and a considerable labour intensiveness (Pryshchepa, 1998).

Today in many countries of the world the seeds treatment is not only necessary but also a legislative obligatory measure for protection of the agricultural crops. According to the data of the Irish experts, about $50 \%$ of winter wheat crops are lost in that region in the absence of presowing seeds treatment against root rots (Strona, 1984).

\section{Literature Review}

In the course of the given research we have analyzed various sources of scientific literature, as well as in 2010-2013 we have carried out our own field experiments at the experimental field of the National Academy of Agrarian Sciences Plant Growing Institute named after V.Ya. Yuryev. The irradiation of winter wheat and spring barley seeds with the electromagnetic fields of the extremely high frequencies (MWF of EHF) was carried out with the help of the equipment of the Kharkiv Technical University of Radio Electronics.

The treatment of seeds with the microwave oscillations of the extremely high frequency electromagnetic field (MWF of EHF) that is widely used for the operation of many radio and home microwave devices was done at the frequency range of $2.5-3.4 \mathrm{GHz}$, at the power of 0.9-1.8 kW for 5-95 seconds per $1 \mathrm{~kg}$ of seeds. The sowing quality of the seeds before and after treatment was determined in accordance with the current State Standard of Ukraine 4138-2002 in the laboratory of the seed production and seed science of the Plant Growing Institute named after V.Ya. Yuryev. The field experiments were c=performed in the crop rotation laboratory of the seed production and seed science. Pea for grain was sown before spring barley and the black fallow preceded winter wheat. During the experiments the area of the studied plot was $20 \mathrm{~m}^{2}$, the recurrence was four-times, and the placement of the plots were systemic.

\section{Discussion}

The treatment with modern preparations makes it possible to disinfect the seeds from the external and internal infections, protect them and their sprouts from the affection with the diseases pathogens, which are in the soil, and to weaken the negative effect of the seeds traumatizing. This also stimulates activation of their protective properties and prevent the development of the pathogens (Handbook ..., 1999).

Unlike the existing presowing technologies of the seeds treatment back in the 80 's of the last century the technologies more ecologically safe became popular. At the Plant Growing Institute named after V.Ya. Yuryev the technology of the presowing seeds treatment called "incrustation" was developed. It combined exactly the treatment and the creation of a protective shell for the seeds (Dindoroho, Strona, 1989). The efficiency of treatment according to this technology is due not only to the effect of the treatment agent, but also to the formation of a protective shell on the surface of the seed, which prevents the access of soil microorganisms to the seeds through the micro-injuries of the endosperm or embryo.

According to the data of the authors who carried out the researches with the seed fungicide Vitavax $200 \mathrm{FF}$ and the preparation Raxil Extra, the development of root rots during the phase of autumn bushing out of winter wheat the variant without treatment was higher than the economic threshold of harmfulness (ETH); it was within the range of $18.5-19.7 \%$. In the case with the use of Vitavax 200 FF and Raxil Extra fungicides, this index was lower in the dry years by $15-34 \%$, and by $60-65 \%$ in the wet years respectively. Thus when 
sown the treated seeds the development of root rots was lower or close to the economic threshold of harmfulness (Krasylovets et al., 2014).

Some researchers point out that the fungicides facilitate the growth and development of plants, while others in their work show the negative influence of the systemic action fungicides on the germination and intensity of the initial growth of the plants (Krasylovets Yu.H. et al., 2014; Batalova, 1989). M.I. Zazimko and other scientists indicate that the studies that had been carried out over 11 years while conducting 47 field experiments showed that only 12 of them led to the significant increase in the yield capacity after presowing treatment of winter wheat (Zazimko et al., 1996).

At the same time the treatment agents provide the sufficient protection of the crops at the beginning of the vegetation, but remain a source of the environmental pollution, they are absorbed by the grain and the stored products and have a negative influence on human health (Pryshchepa, 1998).

According to some authors, the use of chemical preparations for the presowing treatment of seeds suppresses the vitality of the embryo, weakens the productivity of the crops and creates an environment that reduces the immunity during the vegetation period (Babayants, 2014; Yevtushenko, Mariutin, 2001). Such measures are incompatible with the ecologically safe environment and quality of food.

Therefore, the problems of elaboration and research of the new environmentally safe methods for presowing seed treatment, which allow achieving higher yield capacity while minimizing the energy consumption, remains very relevant. In particular, they are relevant in Ukraine where almost the entire territory is declared an ecological disaster zone; the widespread use of chemical preparations can lead to the unpredictable results (Storchous, 2013).

Among the environmentally safe methods of presowing treatment are the thermal methods applied to the seeds of different agricultural crops in order to increase their germination and reduce their contamination with the pathogenic microflora. The hydrothermal seed treatment and stratification (keeping the seeds at a constant temperature for a long period) have such kind of action.

The treatment of seeds with the heated steam at a temperature of $150^{\circ} \mathrm{C}$ also increases the germination. Nevertheless, the disadvantage of the thermal method is the duration of the sowing material treatment procedure (from several hours to several months), as well as high-energy intensity and multi-stage process (Kyrychenko et al., 2009).

The photo-energy methods for the stimulation of the growth processes are applied to both the seed material and vegetative crops. Presowing seed treatment with the impulse focused solar radiation gives an increase in a yield capacity up to $11 \%$; and the treatment of the vegetative plants increases the intensity of the photosynthetic processes proceeding (Dubrov, 1963).

The photo-energy methods also include the laser treatment of the crops sowing material during the vegetation period (Velskyi, Plavinskaya, 2003; Kratzsch, Wicke, Ackermann, 1977). Other ecologically safe and highly effective methods of presowing treatment of seeds are also known.

They are the low frequency electromagnetic field method of treatment (Tbilisi State University); the impulsive concentrated sunlight (Kazakh Agricultural Institute); the infrared radiation (Siberian Scientific and Research Institute of Mechanization and Electrification of Agriculture); the hydrogen and plasma treatment (the Department of National Scientific Centre of Agricultural Electrification); the gradient magnetic field (Joint Institute for Nuclear Researches, the Institute of Physics of the Ukrainian Academy of Sciences), etc. (Shcherbakov, 2002); and the irradiation with the microwave field (MWF) of the extremely high frequencies (EXF) (Odessa Selection and Genetic Institute, Kharkiv National Technical University of Radio Electronics and V.Yu. Yuryev Institute of Plant Growing of NAAS) (Bezpalko, Buriak, 2014; Bezpalko, 2014; Hadzalo, 2009: Cherepnev, 2008; Bashkova, 2007; Havryliuk et al., 2001; Kalinin, Boshkova, 2000).

Increasing the productivity of the grain crops and obtaining the ecologically safe products require the improvement of the cultivation technology, especially in the system of protection the crops from the harmful components of agroceonoses (Litvinov et al., 2003; Lissovyi, 1999).

The presowing seed treatment helps to reduce the negative impact of trauma, improves the yield properties of the seeds by using physical, chemical, biological and other measures aimed at the disinfection, improving the germination and increasing the productivity. In the existing plant protection system, the methods of the presowing treatment of seeds by the nature of their influence are divided into the following basic methods: chemical, biological and physical ones. The treatment of seeds of winter cereals provides not only the effective protection of seeds, sprouts and young plants from the infections but also improves the plants wintering under the conditions of the unfavorable autumn and winter periods. The disinfection of seeds allows to save up to $12 \%$ of winter grain crops, up to $15 \%$ of spring barley with the crops yield capacity of 4.0-5.0 t ha-1 (Smetanko, 2017).

At present, the treatment of seeds not only with the preparation of the fungicidal action but also with those of the insecticide action is becoming more and more widespread (Horban, 2013).

According to the data of the Central Scientific and Research and Project-Technological Institute of Mechanization and Electrification of Cattle-Breeding, the action of the ultraviolet radiation (UVR) provides a $10-12 \%$ increase in the yield capacity of cereals, an increase in the protein content in the green mass of corn by $6-10 \%$ and in the content of sugars by $12-16 \%$. The efficiency of this method of the presowing treatment is confirmed by the testing at the seed research stations (Savelyev, 1981).

The short-term and the repeated short-term treatments of seeds with the focused ultraviolet radiation give an increase in the yield capacity of the cereals up to $10-15 \%$ (Vladykin, 1999).

The mass usage of the growth regulators became possible only after the creation of the preparations on the basis of the natural substances analogues. The literary sources have the illustrations showing that the preparation which rates of applying into the basic crops cultivation amount to dozens of grams or milligrams per 1 ton of seeds or 1 hectare of crops have appeared.

The technology of the presowing treatment with the growth regulators has its own positive features. The preparations are beginning to influence the development of the root system at the initial stages of their development; and such treatment can be carried out in advance together with the treatment agents and film formers at the seed plants or on the farms (Merkushyna, 1994).

As a result of the growth regulators action the mass of the root system increases up to $57 \%$ due to the greater number of the secondary roots in the cereals; the number of little ears in the ear and the mass of 1000 grain also increase. The yield capacity of winter wheat increases up to 6-25\%, and the content of protein in the grain increases by $0.5-1.7 \%$ (Merkushyna, 1994).

O. Holovko found out that the application of the plant growth regulators made it possible to regulate directly the most important processes in a plant organism, to fully realize the potential of the variety laid in the genome by nature and selection (Holovko, 1997). By using a set of the growth regulators in a number of countries, it was possible to achieve an increase in the production of the agricultural output by $15-20 \%$ or even more (Marenych, 2011). 
V.Yu. Sudenko defined that the majority of the preparations for the presowing seeds treatment had not shown the mechanism of their influence on the seed germination, formation of seedlings, density of crops, and the formation of vegetative and reproductive organs of plants (Sudenko, 2016).

Judging by the researches carried out by M.M. Marenych it is seen that the preparations which stimulate the germination of winter crops seeds and protect sprouts from the stress, which is caused by the lack of moisture, have a positive influence on the growth of plants (Marenych, 2011).

A.O. Shevchenko indicates that when using the presowing seeds treatment with the biological stimulators the field germination of winter wheat seeds increases by $5 \%$ on the average (Shevchenko, Anishyn, 1997).

According to the data of A.S. Merkushyna, the effect of all phyto-regulators depends on their concentration; at the same time, the increased concentration causes a sharp inhibition of growth and death of the plants (Merkushyna, 1999).

L.A. Anishyn notes that the treatment of winter wheat seeds with the growth regulator Emistym S significantly enhances the processes of breathing, nutrition and photosynthesis, and increases the accumulation of chlorophyll in the leaves (Anishyn, 1999a). In the KSP "Ukraine" of the Bucha district in the Ternopil region, as well as in a number of other farms, the yield capacity of winter wheat after the use of Emistin S has increased by $0.50-0.62 \mathrm{t} \mathrm{ha}^{-1}$ (Anishyn, 1999b). At the same time, it was found that the dose of the treatment agent could be reduced by $25-30 \%$ when combined the treatment of winter wheat seeds with the plant growth regulator Emistym S. Such combination does not reduce their protective effect, which allows saving the costs. The treatment of seeds with the growth regulators also significantly improves the quality of the bread baked from the winter wheat flour (Ponomarenko, 1999).

L.Yu. Kerefov (2004) indicates that when treated the winter wheat seeds with Emistym $\mathrm{S}$ at a dose of $10 \mathrm{ml} \mathrm{t}^{-1}$, there was an increase in the yield capacity by $0.36 \mathrm{t} \mathrm{ha}^{-1}$. The treatment with Agrostymulin in the same dose gave an increase by $0.44 \mathrm{t}$ ha ${ }^{-1}$ at a yield capacity under the control of $4.97 \mathrm{t} \mathrm{ha}^{-1}$ (Kerefov, 2004).

With modern technologies of grain crops cultivation the presowing incrustation of seeds with a bank mixture consisting of the filmformer, growth regulator and the treatment agent is a very important element of technology that contributes to increasing the resistance of plants to the stress weather conditions, and as a result to increase their productivity (Sharypin, 1998).

Under the conditions of the unstable moistening of the Northern Steppe the use of the plants growth regulators for the presowing seeds treatment of spring chaffy barley facilitated the increase in the crop productivity by $0.12-0.54 \mathrm{t} \mathrm{ha}^{-1}$, that is $3.1-13.8 \%$ (Sudenko, 2016).

According to the researches of Ponomarenko S.P. the high efficiency of growth regulators is due to their content of a balanced complex of the biological substances which accelerates the growth of the green mass and the root system, and therefore the nutrients are used more actively, resulting in the increased resistance of the crops to the diseases, stress and unfavorable weather conditions (Ponomarenko, 1999).

Smetanko O.V. notes that the use of the biological preparations based on the microorganisms Bacillus polymyxa, Enterobacter nimipressuralis, Aehromopacter album is positively marked on the winter wheat grain quality indices. Thus, when using the nitrogenous fertilizers together with the preparation based on Bacillus polymyxa, a mathematically significant increase in the content of gluten was noted (Smetanko, 2017).

The most promising element of the modern technologies for growing winter wheat and spring barley is the presowing seeds treatment with the biological preparations that stimulate germination, protect the seeds from the diseases, and eliminate the environmental pollution.

Recently due to the excessive pollution of the environment resulting in a wide and uncontrolled use of the pesticides and mineral fertilizers, the search for the alternative agricultural systems is very relevant. These systems are based on the biologization that foresees the limitation, and in the perspective the refusal from the chemical agents, the expansion of new types of the biological means usage for plant protection, especially under the unfavourable environmental conditions (Krasylovets et al., 2014).

During the experiments of the Plant Growing Institute named after V. Ya. Yuryev of NAAS and other scientific and research institutions of Ukraine the influence of various methods of the presowing seeds treatment has being studied for many years. These methods include the use of plant growth regulators, biological preparations, seed incrustation, ozonization, physical methods of treatment and their combination. The scientists compare the action of the above-mentioned methods with the action of the chemical treatment agents as for the effect, which they have on the yield capacity, and the quality indices of many agricultural crops (Kindruk, Havryliuk, 2007).

The intensive use of the chemical agents for the presowing treatment of seeds facilitates the increase in the crops productivity but at the same time inevitably causes a number of undesirable effects of the ecological and economic character. The ecological consequences of using pesticides are reinforced by their cumulative effect, which is very dangerous for the quality of the obtained products. These substances are not natural, and therefore cause cankerogenosis and mutagenic effects. At the same time, the disinfection of the seed material is an obligatory agro-technical measure in the technology of the agricultural crops cultivation; and it will be impossible to solve the problem of the crops yield capacity increasing without it. Therefore, the scientists and practitioners in a number of countries of the world are passing on to the alternative methods of the presowing seeds treatment (Kindruk, Havryliuk, 2007).

One of the most ecologically safe methods of the presowing seeds treatment is the irradiation with the microwave field (MWF) of the extremely high frequencies (EHF).

With the development of organic agricultural production in Ukraine, the rates of the chemicals in the agro-systems are significantly reduced. Beginning from 2004 in the EU the use of the traditional methods for the chemical treatment of seeds has been forbidden on the farms with the organic agriculture. This fact has led to the search for the new methods of the presowing seeds treatment, and first of all the physical methods became an alternative to the chemical ones (Dryncha et al., 2010). However, unlike the chemical treatment, the physical methods (high frequency and microwave methods and treatment with the warm air or water) do not influence the diseases that are communicated to the plants through the soil organisms.

The method of treating seeds with the heat belongs to the physical methods of the seeds treatment and can be used in practice; this method was known long ago. The seeds are heated with water, steam or air. The main criterion here is a combination of the temperatures factor, which is critical for the harmful organisms and the seeds. The main disadvantage of this method is the high moisture content in the seeds after treatment, which leads to significant consumption of energy necessary for the seeds drying (Presman, 1956).

Recently the methods with the use of the electromagnetic field (EMF) of the extremely high frequency (EHF) range in the food industry (microwave ovens) and for the drying of food and agricultural products have been widely used. 
The use of the high-frequency electromagnetic waves of the microwave range for the seeds treatment is characterized by a significant intensity of heating, as well as the penetration of heat into the internal grain tissues (Boshkova, 2007). The possibility of the seeds germination significantly reduces. This method is not suitable in practice, because when drying the seeds surface they die together with the pathogens of the disease.

In 1956 scientist A.S. Presman proposed to use the action of the electric waves not only as the heat energy, but also as a catalyst for the processes taking place against the background of heating (Presman, 19580). He assumed that the electromagnetic field (EMF) had an information influence on the biological objects (Leus, Kolomyichuk, 2009).

At the present stage the possible influence mechanisms of EMF on the plant organisms are relatively divided into several levels (Kalinin et al., 2002). Firstly, it is the energy effect that has the physical and mechanical bases of the heat effect (an increase in temperature and local pressure) and it is the most known. The most uncertain level is the information one, when the external energy flow cannot make the significant changes in the thermodynamics of the biological processes, but it can affect the vital processes of the plant organisms. This approach is implemented at the cellular level and is connected with the biological structures. These are the elements of the cell membranes that have a significant dipole electric moment (molecules of the protein and enzymes, etc.) (Kalinin et al., 2002). The information component today has an increased scientific interest for the physicists as well as for the biologists.

Among the physical methods of the presowing seeds treatment the most promising method is the microwave (MW) technology; it is a result of many years of the researches of the military-industrial complex scientists and the branch sciences (Shevchenko et al., 2007; Shevchenko, 1999). Many years of scientific experiments and the experience of a number of agricultural producers confirm that the microwave field suppresses the entire complex of the seed infection, which creates an alternative to the chemical method of plant protection (Paramonov, 2013; Shevchenko, 1999; Presman, 1956).

The use of microwave complexes for the seeds stimulation by the specialists of the leading research institutions, both in Ukraine and abroad, made it possible to identify the reserves for increasing the yield capacity of the agricultural crops. According to the results of a number of the authors, the attention to the physical method of the presowing seeds treatment with the microwave field consists in the fact that in this case a number of technological and economic issues are solved (Kalinin et al., 2002; Ryzhuk et al., 2000; Rivis, Kovalysyn, 2000; Heidecker, 1982). These main issues are increasing the laboratory and field germination of the seeds, accelerating the development of the crops and their ripening; resistance to the frosts, droughts, pests and pathogens; the increase in biomass; quality improvement of products (starch, protein, etc.); disinfection of the seeds and obtaining ecologically pure production with a reduced content of nitrates and pesticides. The researches concerning the testing of the microwave technology for the seeds stimulation in order to increase the level of the crops productivity potential realization (Kindruk, Havryliuk, 2007) occupy a special place in increasing the crops yield capacity (Havryliuk et al., 2001; Peresypkin, 1989); and it is very important thing.

The results of the researches carried out at the Selection and Genetic Institute of the National Academy of Agrarian Sciences indicate that after treating three varieties of the elite seeds of soft winter wheat with the microwave field, the laboratory germination increased by $2-3 \%$; and the initial indices were $95-96 \%$. The field germination exceeded the control by $10-12 \%$, and the yield capacity was exceeded by $12.1-33.6 \%$ depending on the variety. The efficiency of the wheat seeds treated with the microwaves has been confirmed by the experiments at the genetic level (Kindruk, Havryliuk, 2007).

In Ukraine, the new technology of the presowing treatment of winter wheat seeds has been tested under the very severe winter conditions of 2002-2003, when the winter cereals were destroyed by frost on a large area. According to the data of the Vinnytsia Research Station the seeds of Donetska 48 wheat variety, treated with the microwave field, not only passed the winter but also yielded $2.5 \mathrm{t} \mathrm{ha}^{-1}$ while under the control (the seeds without treatment) the plants died.

It is known that among the methods that stimulate the growth processes and accelerate the growth and development of plants, the physical, chemical and biological methods are distinguished. According to the authors none of them has become widely used because they are not well grounded, and the mechanisms of their effect and after effect on the seeds have not been disclosed yet (Shevchenko, Tuchnyi, 2007)

The effect of the seeds biological stimulation with the energy of the microwave field is manifested itself in different ways depending on the genotype of the plants, the variety reaction, as well as on the initial quality of the seeds. According to the data of the researches with winter cereals (wheat and barley) this effect is smoothed over by the conditions of the autumn and winter periods, but even in those years the increase in the yield capacity was mainly reliable (Tymoshenko et al, 2009). With the spring cereals the effect of the seeds microwave stimulation is better than with the winter cereals due to more favorable conditions and a short vegetative period of the crops, when the energy of the microwave field has a greater aftereffect on the plant (Bezpalko, Buriak, 2014; Technology of microwave treatment of agricultural crops seeds, 2003).

The dry conditions of the summer period in the south of Ukraine are particularly vulnerable to the spring cereals. The researches of the Odessa Agrarian University scientists conducted in the very hot summer of 2003 show that the yield capacity of nine varieties of spring barley which seeds had been treated with the microwave field, exceeded the crops under the control by $0.3-0.5 \mathrm{tha}^{-1}$ while an average yield capacity in the region as a result of the drought was $0.83 \mathrm{t} \mathrm{ha}^{-1}$ (Presman, 1956).

The authors at the functional level, namely the third one after the energy and information levels (Kalinin et al., 2002), carried out the study of the possible mechanisms of the microwave field action on the biological objects. The optimum regimes of EMF that activate the action on the enzymatic systems of the agricultural crops seeds were found; at the same time the structural and functional integrity and biochemical composition of the treated seeds were not damaged. During the vegetation period, the intensity of the assimilation processes has been reinforced.

According to the authors the unique character and practical significance of the microwave technologies consists in the fact that along with the increase in the productivity of the field crops the industrial loading on the natural environment is weakened. The technology minimizes and often completely excludes the use of chemical preparations, among which the pesticides are particularly dangerous. Their decomposition in the soil, plants and water is often accompanied by more resistant and toxic elements in comparison with the initial compounds (Buriak et al., 2011; Technology of microwave treatment of agricultural crops seeds, 2003).

The obtained data and the gained experience of using different EMF regimes have been thoroughly tested under the laboratory conditions and at the experimental plots of different farms and they are recommended to be used in the agricultural practice of the presowing seeds treatment.

Along with the physical methods of treating the seed material with the microwaves, the biological preparations based on the useful microorganisms are widely used in the agricultural practice (Bezpalko, Buriak, 2014; Tymoshenko et al., 2009; Tuchnyi, 2007).

The recent studies have shown that among the new non-traditional reserves of the spiked cereals productivity increasing, which do not require the significant additional costs, there is a widespread introduction of the plant growth regulators of the new generation (Chmil, Lazariuk, 2016; Hadzalo, 2009; Gordiyenko, Ponomarenko, 2008; Piatyhin, 2008; Voloshyna, 2007). 
In the decree of the Ministry of Agrarian and Industrial Complex and Ukrainian Academy of Agrarian Sciences dated 18.10.1999, No.303/113 "On the Introduction of New Growth Regulators", it is emphasized that the Ukrainian preparations are one of the most profitable reserves for increasing the yield capacity. This is especially true under the conditions of the insufficient nutrition of soils; and beginning from 2000, the new growth regulators are recommended to be used by the farm specialists as an obligatory agricultural measure (Recommendations on the use of highly effective plant growth regulators in the cultivation of spiked cereals, 2005).

The growth regulators in very small doses facilitate the acceleration of growth, development, increase in productivity and improve the quality of the agricultural products. Penetrating into the plants, they are included in the metabolism, activate the biochemical processes, and increase the level of vital activity of the plants. The regulators influence the system of hormonal regulation, which determines the nature of the most important physiological processes, in particular, accelerates the formation of new organs of the plants and the beginning of flowering and ripening (Bezpalko, Buriak, 2014).

At the experimental crops of the Chernihiv Agricultural Station the number of the productive stalks of winter wheat increased by 16.1 $17.1 \%$ under the influence of the biological stimulators (Kossolap, 2008).

In the nearest future the combination of the microwave technology and the subsequent treatment of the seeds with the plant growth regulators should become a perspective direction of science and practical agriculture; this will enable to solve a number of the agricultural production problems in a complex.

The high energy of germination characterizes the ability of the seeds to germinate quickly and simultaneously. Healthy seeds, smoothed according to their physiological state, have such a property. Quick and simultaneous seed germination shows that the sprouts will be strong and resistant to the unfavourable environmental conditions during sowing and sprouting (Izhyk, 1976).

The main manifestations of the electromagnetic field influence on the seeds as a biological object are the thermal effect (the temperature increase) and the functional effect. The latter is breaking of the hydrogen links and occurrence of processes of starch hydration with the formation of the final biochemical components such as glucose and fructose and other enzyme transformations, which subsequently affect the stimulation and intensification of germination (Dindoroho and others, 2009; Kalinin, Boshkova, 2000).

By the authors' determination these effects are appearing simultaneously; but to draw a conclusion as for the degree of the biological effect as a result of the seeds presowing irradiation with the microwave field of the extremely high frequency can be possible only by determining the quality indices of the seeds, and first of all, the energy of germination and sprouting.

In this connection we have carried out the reconnaissance experiments in order to establish the optimum regimes for spring barley and winter wheat seeds irradiation with the microwave field of an extremely high frequency in the range of $2.5-3.4 \mathrm{GHz}$ with the help of the equipment of the Kharkiv National University of Radio Electronics. The optimum regime for the seeds irradiation is that which does not lead to a decrease in the germination or causes its increase, but the effect of brining the seeds into a healthy state is kept at the subsequent stages of the plants development.

The seed samples by weight of $200 \mathrm{~g}$ each were irradiated with a microwave field of the extremely high frequencies. The irradiation power of 0,9 or $1,8 \mathrm{kw}$ per $1 \mathrm{~kg}$ of seeds at the variable exposure (exposure duration) at the intervals of 5 seconds (from 5 to 95 seconds) was studied. It was found out that the temperature of the seeds increased and ranged from 20 to $87^{\circ} \mathrm{C}$ depending on the exposure. Seven days after the irradiation the samples were sown in order to determine the laboratory germination according to the State Standard of Ukraine 4138-2002 (The Seeds of Agricultural Crops; 2003).

The indices of the germination and sprouting energy of the irradiated barley and wheat seeds varied depending on the radiation power and its exposure; and the sowing quality of the seeds that had been irradiated with the high regimes "a dose-an exposition" decreased significantly or even led to the death of the embryos.

According to the results of the researches, the conformities of the variability of the germination and sprouting energy of spring barley seeds of Aspect variety depending on the temperature of the seeds heating and the exposure of the radiation were determined. At the power of $0.9 \mathrm{~kW}$ per $1 \mathrm{~kg}$ of the seeds the slight fluctuations of the germination and sprouting energy are observed. Thus, at the exposures from 5 to 40 seconds the germination energy was within the limits of 88-92\%; at the exposure of 45 seconds it was $93 \%$. The further increase in the radiation exposure of the seeds up to 50-80 seconds led to a decrease in the energy of germination, it amounted to $88-92 \%$. In this case the seeds germination at the exposure from 5 to 40 seconds was within the limits of $90-93 \%$, at the exposures of $45-50$ seconds it was $93 \%$. The further increase in the radiation exposure of the seeds up to $55-80$ seconds led to a decrease in the sprouting and it was $90-92 \%$. Thus, the highest indices of the germination and sprouting energy of the seeds (93\%) at the power of $0.9 \mathrm{~kW}$ per $1 \mathrm{~kg}$ of seeds were observed at the exposure of 45 seconds.

When irradiating the seeds at the power rate of $1.8 \mathrm{~kW}$ per $1 \mathrm{~kg}$ of seeds and at the exposures from 5 to 15 seconds the seeds germination energy was $89 \%$ and the energy of the seeds sprouting was $91-92 \%$. The highest energies of germination and sprouting were obtained at the exposure of 20 seconds; they were 91 and $92 \%$ respectively. An increase in the exposure from 25 to 50 seconds was accompanied by a sharp decrease in the energy of the seeds germination and sprouting and it reached $88-45 \%$ and $89-55 \%$ respectively. Therefore, for the conducting the field researches while irradiating the seeds at the power rate of $1.8 \mathrm{~kW}$ per $1 \mathrm{~kg}$ of seeds, the exposure that lasted 20 seconds was chosen.

According to Dindoroho at al (2009), a regular character for each variety was found out. At a certain exposure of radiation, before the "threshold" of a significant decrease in the sprouting, its maximum increase occurred, which in many cases exceeded the index under the control.

The presowing seeds treatment with the microwave field of the extremely high frequencies increased the laboratory germination by $2 \%$ at the irradiation rate of $1,8 \mathrm{kw}$ per $1 \mathrm{~kg}$ of seeds and at the exposure of 20 seconds; at the rate of $0.9 \mathrm{Ww}$ per $1 \mathrm{~kg}$ of seeds and the exposure of 45 seconds the germination increased by $4 \%$.

Thus at the exposure from 0 up to 30 seconds the germination energy was within the limits of $88-89 \%$, at the exposure of $35-40$ seconds it was $90 \%$, and at the exposure of 45 seconds it was $91 \%$. The further increase in the seeds irradiation exposure up to $50-80$ seconds resulted in a significant reduction in the energy of germination; it was $85-86 \%$. At the same time the seeds germination at the exposure from 0 to 15 seconds was within the limits of $89 \%$, at the exposure of 20 to 40 seconds it was $90 \%$, and at the exposure of 45 seconds it was $91 \%$. The further increase in the seeds irradiation exposure up to $50-80$ seconds led to a significant decrease in the germination; it was $86-88 \%$. Thus the highest indices of the seeds germination and sprouting (at the level of $91 \%$ ) at the power of 0.9 $\mathrm{kW}$ per $1 \mathrm{~kg}$ of seeds were observed at the exposure of 45 seconds.

The most optimum exposure of the irradiation of winter wheat Astet variety with MWF of EHF at a power rate of $1.8 \mathrm{~kW} \mathrm{~kg}{ }^{-1}$ of seed is 15 seconds. Here the maximum indices of the germination and sprouting energies have been noted, these indices were at the level of $93 \%$; while under the control without treatment the indices were 88 and $89 \%$ respectively. At the exposures of irradiation from 5 to 10 seconds the germination and sprouting energies were less, namely $90-91 \%$ and $91-92 \%$ respectively. The increase in the exposure 
from 20 to 30 seconds was accompanied by a sharp decrease in the energy of the seeds germination and sprouting, namely $85-87 \%$ and $86-88 \%$ respectively.

In the complex of the technological methods of the agricultural crops cultivation, the preparation of seeds for sowing is an obligatory component. Usually the pre-sowing seeds preparation consists in disinfecting the seed material with the seed treatment agents as well as treating it with the synthetic preparations of different origins that stimulate the sowing and yield quality of the seeds (Petrovskyi et al., 2011; Retman, 2009; Strona, 1984; Mandzhos, 1971).

At the same time in Ukraine and other countries of the world, the researches concerning the study of the efficiency of the nontraditional and ecologically safe methods of the presowing seeds treatment are being carried out. One of such methods is the microwave irradiation of the extremely high frequencies. According to Bezpalko, Buriak (2014), Buriak et al. (2011), Khomenko et al. (2009) the use of the microwave technology does not exclude the possibility of its combination with the treatment of seeds with the biological and chemical preparations

That is why the next stage of the reconnaissance laboratory researches was the study of the influence of the additional presowing treatment of barley and wheat seeds irradiated with the microwave field of the extremely high frequencies, the seeds treatment agent and plant growth regulators on the indices of the germination and sprouting energy.

For this purpose after the irradiation with the microwave field of the extremely high frequencies the presowing treatment of spring barley seeds of Aspect and Vyklyk varieties with the growth regulators of Radostym and Albit and the seed treatment agent Vitavax 200 FF was carried out. During the experiments the recommended rates of the preparations consumption as well as the half-reduced rates were tested (List of pesticides..., 2012).

It was found out that treating the seeds with Vitavax $200 \mathrm{FF}$ at the half-reduced rate from the recommended one gave an increase in the energy of germination and laboratory sprouting by $2 \%$, whereas the total rate of the seed treatment agent did not provide an increase in the sowing qualities.

The use of the reduced rates of plant growth regulators Radostym and Albit proved to be less effective in comparison with the total rate of their usage. In the first case the sprouting increased only by $1-3 \%$, while in the second case it increased by $2-4 \%$.

Consequently, for the further laboratory and field studies a half-rate of Vitavax $200 \mathrm{FF}$, namely 25 I $\mathrm{t}^{-1}$ and a total rate of plant growth regulators Radostym and Albit at the rates of $0.25 \mathrm{I} \mathrm{t}^{-1}$ and $30 \mathrm{ml} \mathrm{t}^{-1}$. respectively for the presowing treatment of the seeds irradiated with the microwave field of the extremely high frequencies were used. We have taken the growth regulator Mars EL at the manufacturer's recommended rate of $0.2 \mathrm{It}^{-1}$ for the researches with winter wheat.

\section{Conclusion}

The nature of the presowing irradiation with the microwave field of the extremely high frequencies influence on the sowing quality of spring barley and winter wheat depends on the intensity of the irradiation and its exposure, as well as the associated temperature of the seeds heating.

The positive influence on the energy of germination and the seeds sprouting of spring barley seeds was noted at the power of the irradiation with the microwave field of the extremely high frequencies of $1.8 \mathrm{~kW} \mathrm{~kg}^{-1}$ and at the exposure of 20 seconds. This was also the same at power of $0.9 \mathrm{~kW} \mathrm{~kg}^{-1}$ and at the exposure of 45 seconds. As for winter wheat seeds the best results was noted when irradiating them at the power of $1.8 \mathrm{~kW} \mathrm{~kg}^{-1}$ and at the exposure of 15 seconds, as well as at the power of $0.9 \mathrm{~kW} \mathrm{~kg}^{-1}$ and an at the exposure of 45 seconds.

The treatment of spring barley and winter wheat seeds irradiated with the microwave field of the extremely high frequencies at a halfreduced rate of consumption, namely $1.25 \mathrm{t}^{-1}$ or its treatment with the growth regulators contributes to an additional increase in the sowing quality of the seeds and depends on the preparation and its rate of consumption.

To increase the ecological safety of the existing cultivation technologies and the yield capacity of winter wheat and spring barley, the presowing seeds treatment with the chemical agents should be replaced by the presowing irradiation with the microwave field of the extremely high frequencies (MWF of EHF). The rates and methods should be crop-specific. It will has a special importance in organic agriculture.

\section{References}

Anishin L. (2002). Regulyatori rostu roslin: sumnivi i fakti. Propoziciya, 5, 64-65 (in Ukrainian).

Anishin L.A. (1999a). Vpliv biostimulyatoriv na vrozhaj i yakist ozimoyi pshenici. Novini zahistu roslin, 7/9, 29-30 (in Ukrainian).

Anishin L.A. (1999b). Biostimulyatori dlya ozimoyi pshenici. Silskij chas, 10(2) (in Ukrainian).

Babayanc O.V. (2014). Zastosuvannya preparativ novogo pokolinnya u virobnictvi zernovih kolosovih kultur. Nasinnictvo, 2, 2. (in Ukrainian).

Batalova T.S. (1989). Zashita zernovyh kultur ot golovnevyh zabolevanij i kornevyh gnilej: rekomendacii. Moscow. Agropromizdat (in Russian).

Bespalko V.V., Buryak Yu.I. (2014). Vliyanie predposevnoj obrabotki semyan mikrovolnovym polem v sochetanii s regulyatorom rosta i biopreparatom na posevnye kachestva i urozhajne svojstva yachmenya yarovogo. Zernobobovye i krupyanye kultury: nauchno-proizvodstvennyj zhurnal, 4, 133-139. (in Ukrainian).

Bezpalko V.V. (2014). Vpliv ekologichno bezpechnih sposobiv peredposivnoyi obrobki nasinnya na urozhajnist i yakist zerna pshenici ozimoyi. Visnik Harkivskogo Nacionalnogo Tehnichnogo Universitetu Silskogo Gospodarstva im. P. Vasilenka, 152, 100-108. (in Ukrainian).

Boshkova I.L. (2007). O mehanizmah vliyaniya mikrovolnovogo polya na semena. Mikrovolnovye tehnologi v narodnom hozyajstve, 6, 19-22. (in Russian).

Buryak Yu. I. (2011). Vpliv ristregulyuyuchih preparativ i mikrohvilovogo oprominennya posivnogo materialu na vrozhajnist ta posivni yakosti nasinnya yachmenyu yarogo. Osnovi biologichnogo roslinnictva v suchasnomu zemlerobstvi: Proceed. Int. Conf. Uman. (in Ukrainian).

Cherepnev A.S. (2008). Ispolzovanie impulsnogo elektromagnitnogo izlucheniya dlya obezzarazhivaniya zernovoj smesi. Zbirnik naukovih prac Harkivskogo universitetu Povitryanih Sil im. I. Kozheduba, 2(17), 53-55. (in Russian).

Chmil A.I., Lazaryuk K.O. (2016). Analiz suchasnih NVCh-ustanovok dlya peredposivnoyi obrobki nasinnya silskogospodarskih kultur. Energetika i avtomatika, 2, 156-163. (in Ukrainian).

Dindorogo V.G. (2009). Vpliv MH-stimulyaciyi nasinnya zernovih kolosovih kultur na pidvishennya posivnih yakostej ta vrozhajnih vlastivostej nasinnya. Mikrovolnovye tehnologii v narodnom hozyajstve, 7-8, 82-85. (in Ukrainian). 
Dindorogo V.G., Strona I.G. (1989). Inkrustirovanie semyan polevyh kultur i perspektivy ego vnedreniya v proizvodstvo. Teor. i prakt. pred. obrabotki semyan. Kiev (in Russian).

Drincha V.M., Cydendorzhiev B.D., Kubeev E. (2010). Osnovnye principy predposevnogo himicheskogo protravlevaniya i fizicheskogo obezzarazhivaniya semyan. Hranenie i pererabotka zerna, 12(158), 20-22. (in Russian).

Dubrov A.P. (1963). Dejstvie ultrafioletovoj radiacii na rasteniya. Moscow: USSR Academy of Science Press (in Russian).

Fokin A. (2009). Protruyennya nasinnya: istoriya ta suchasnij asortiment. Propoziciya, 2,. 8-10. (in Ukrainian).

Gadzalo Ya.M. (2009). Mikrovolnovaya tehnologiya - shag v budushee agrarnoj otryasli. Hranenie i pererabotka zerna, 5(119), 26-28. (in Russian).

Gavrilyuk N.N. (2001). Ocenka effektivnosti MV - biostimulyacii ozimoj pshenicy s pomoshyu izolirovannyh zarodyshej i in vitro. Hranenie i pererabotka zerna, 11, 24-26. (in Russian).

Golovan L.V., Klymenko I.V. \& Stankevych S.V. (2019). The inheritance of economically valuable features in the intraspecific hybridization of bean (Phaseolus L). Ukrainian Journal of Ecology, 9 (2), 156-169.

Golovko O. (1997). Visokij vrozhaj zavdyaki vitchiznyanim biostimulyatoram. Uryadovij kur'yer, 22.02, 9 (in Ukrainian).

Gorban G.S. (2013). Vdale protruyuvannya - proste rishennya rozkrittya potencialu kulturi. Agronom, 1, 102-103. (in Ukrainian).

Gorban G.S. (2013). Protruyuvannya nasinnya - osnovnij zahid dlya kontrolyu hvorob. Propoziciya, 9, 78-81. (in Ukrainian).

Gordienko L. E., Ponomarenko S. P. (2008). Vypolnenie Kiotskogo protokola po umensheniyu vybrosov uglekislogo gaza putem povsemestnogo primeneniya regulyatorov rosta rastenij. Biologicheskie preparaty v rastenievodstve: Proceed. Int. Conf. (Radostim 2008). Kiyiv (in Russian).

Hajdeker U. (1982). Fiziologiya i biohimiya prorostaniya semyan. Moscow: Kolos (in Russian).

Homenko G.V. (2009). Sovmestnoe primenenie mikrovolnovoj obrabotki i biopreparatov protiv kornevyh gnilej i drugih zabolevanij rastenij. Mikrovolnovye tehnologii v narodnom hozyajstve, 6, 67-68. (in Russian).

Izhik N.K. (1976). Polevaya vshozhest semyan (biologiya, ekologiya, agrotehnika). Instit. agroh. i pochvoved. UAAN. Kiev: Urozhaj (in Russian).

Kalinin L.G. (2002). Kompleks rabot po issledovaniyu vliyaniya MV na processy biostimulyacii kultur. Hranenie i pererabotka zerna, 3, 31-34. (in Russian).

Kalinin L.G. (2002). Rezultaty povysheniya urozhajnosti polevih kultur pri obrabotke semyan mikrovolnovym polem. Hranenie i pererabotka zerna, 1, 28-31. (in Russian).

Kalinin L.G., Boshkova I.L. (2000). Vliyanie mikrovolnovogo elektromagnitnogo izlucheniya MVEMI na biologicheskie obekty. Mikrovolnovye tehnologii v narodnom hozyajstve. Vnedrenie, problemy, perspektivy, 2/3, 108-112. (in Russian).

Kerefova L.Yu. (2004). Pro vpliv regulyatoriv rostu na yakisni pokazniki zerna ozimoyi pshenici. Zernovoe hozyajstvo, 4, 4-5. (in Ukrainian). Kindruk M.O., Gavrilyuk M.M. (2007). Mikrohvilova stimulyaciya nasinnya: problemi ta perspektivi yiyi zastosuvannya. Mikrovolnovye tehnologi v narodnom hozyajstve, 6, 36-38. (in Ukrainian).

Kirichenko V.V. (2009). Ozonova tehnologiya peredposivnoyi obrobki nasinnya silskogospodarskih kultur. Posibnik ukrayinskogo hliboroba. Harkiv (in Ukrainian).

Kosolap N.P. (2008). Allelopatiya - prichina mnogih posledstvij. Zerno, 9, 46-51. (in Russian).

Krasilovec Yu.G. (2014). Efektivnist Vitavaksu 200 FF na posivah pshenici ozimoyi ta yachmenyu yarogo $v$ umovah shidnoyi chastini Lisostepu Ukrayini. Agro Elita: vseukrayinskij agrarnij zhurnal, 1(12), 26. (in Ukrainian).

Kratzsch G., Wicke H., Ackermann D. (1977). Standort und sortenspezifische Aubauempfehlungen fur eine effektive produktion von Brau und Futtergerste. Feldwirschaft, 1, 14-17.

Leus N.F., Kolomijchuk S.G. (2009). Effektivnost primenenie mikrovolnovoj tehnologii v agromromyshlennom komplekse. Mikrovolnovye tehnologii v narodnom hozyajstve. Odessa, 7/8, 86-88. (in Russian).

Lihochvor V. (2003). Zastosuvannya regulyatoriv rostu roslin (morforegulyatoriv, retardantiv) na posivah zernovih kultur. Propoziciya, 3-4, 56-57. (in Ukrainian).

Lisovij M.P. (1999). Dovidnik iz zahistu roslin. Kiyiv: Urozhaj (in Ukrainian).

Litvinov V.A. (2005). Reakciya novyh sortov yarovogo yachmenya na predshestvenniki. Zemledelie, 3, 43. (in Russian).

Manzhos D. M. (1971). Nasinnyeznavstvo pshenici. Kiyiv: Urozhaj (in Ukrainian).

Marenich M.M. (2011). Vpliv peredposivnoyi obrobki nasinnya ta mineralnogo zhivlennya na formuvannya elementiv strukturi vrozhajnosti pshenici m'yakoyi ozimoyi. Visnik Poltavskoyi derzhavnoyi agrarnoyi akademiyi, 1, 169-172. (in Ukrainian).

Merkushina A.S. (1999). Fitoregulyatori ta mikroelementi v zahisti roslin. Visnik agrarnoyi nauki. Spec. Vip, 54-57. (in Ukrainian).

Merkushina A.S. (1994). Fiziologo-biohimichni osnovi diyi giberelinu na roslini gorohu ta fitovagi. Biologo-ekologichni osnovi viroshuvannya silskogospodarskih kultur v umovah Lisostepu. Kiyiv: Silgosposvita (in Ukrainian).

Nasinnya silskogospodarskih kultur. Metodi viznachennya yakosti. (2003). DSTU 4138-2002. Kiyiv: Derzhstandart (in Ukrainian).

Paramonov K.Yu. (2013). Mikrohvilova pich zamist protrujnika. Parostok, 2,. 7. (in Ukrainian).

Perelik pesticidiv i agrohimikativ, dozvolenih do vikoristannya v Ukrayini (2012). Kiyiv: TOV Yunivest Prin (in Ukrainian).

Peresypkin V.F. (1989). Selskohozyajstvennaya fitopatologiya. Moscow: Agropromizdat (in Russian).

Petrovskij O.M. (2011). Temperaturnij rezhim UVCh oprominennya, yak faktor vplivu na shozhist nasinnya pshenici. Zbirnik naukovih prac Vinnickogo agrarnogo universitetu. Seriya: Tehnichni nauki, 7, 24-28. (in Ukrainian).

Ponomareno S.P. (1999). Regulyatori rostu. Ekologichni aspekti zastosuvannya. Zahist roslin, 12, 15. (in Ukrainian).

Presman A.S. (1958). Elektromagnitnye polya i zhivaya priroda. Moscow: Nauka (in Russian).

Presman A.S. (1956). O fiziologicheskih principah biologicheskogo dejstviya santimetrovyh voln. Uspehi sovremennoj biologii, 1, 10. (in Russian).

Prishepa I.A. (1998). Primenenie smesi pesticidov i regulyatorov rosta na posevah zernovyh kolosovyh kultur. Agrohimiya, 8, 74-89. (in Russian).

Pyatygin S.S. (2008). Stress u rastenij: fiziologicheskij podhod. Zhurn. obsh. Biologii, 69(4), 294-311. (in Russian).

Rekomendaciyi iz zastosuvannya visokoefektivnih regulyatoriv rostu roslin pri viroshuvanni kolosovih zernovih kultur (2005). Mizhvidomchij naukovo-tehnichnij centr «Agrobioteh» NAN ta MON Ukrayini. Kiyiv (in Ukrainian).

Retman S.A. (2009). Mikrohvilova tehnologiya v kompleksnij sistemi zahistu roslin. Mikrovolnovye tehnologii v narodnom hozyajstve, 6,. 6263. (in Ukrainian).

Rivis J.F., Kovalishin S.J. (2000). Optimalni parametri rezhimiv peredposivnoyi elektrostimulyaciyi nasinnya. Visnik agrarnoyi nauki, 6, 2830. (in Ukrainian).

Rizhuk S.M. (2000). Tehnologiya mikrohvilovoyi obrobki nasinnya silskogospodarskih kultur. Agrarna nauka: Proceed. Sci. Conf. Kiyiv (in Ukrainian).

Savelev V.A. (1981). Fizicheskie sposoby obrabotki semyan i effektivnost ih ispolzovaniya. Sibirskij vestnik s-h. Nauki, 5, 26-29. (in Russian). 
Sekun M.P. (2007). Dovidnik iz pesticidiv. Kiyiv: Kolobig (in Ukrainian).

Sharipin V.O. (1998). Regulyatori rostu roslin u zemlerobstvi. Pp. 44-48. Zbirnik nauk. prac. A.O. Shevchenko (Ed.). (in Ukrainian).

Sherbakov K.N. (2002). Stimulyaciya rostovyh processov rastenij nizkoenergeticheskim magnitnym polem. Mehanizaciya i elektrifikaciya selskogo hozyajstva, 7, 26-29. (in Russian).

Shevchenko A.M. (2007). Znachenie mikrovolnovoj tehnologii v narodnom hozyajstve. Mikrovolnovye tehnologii v narodnom hozyajstve, 6 , 8-9. (in Russian).

Shevchenko A., Anishin L. (1997). Rezerv pshenichnoyi nivi. Biostimulyatori rostu novogo pokolinnya. Zahist roslin, 10, 21. (in Ukrainian).

Shevchenko A.M., Tuchnyj V.P., Malinovskij V.V. (2007). Novye tehnologii - za chistoe zemledelie. MV tehnologii v narodnom hozyajstve, 6 , 76-79. (in Russian).

Shevchenko O.I. (1999). Resursozberigayucha tehnologiya viroshuvannya yachmenyu yarogo u pravoberezhnomu Lisostepu i Polissya Ukrayini. Proceed. Int. Conf. Harkiv (in Ukrainian).

Shpaar D. (1996). Alternativnoe zemlepolzovanie. Himiya v selskom hozyajstve, 2, 40-43. (in Russian).

Smetanko O.V. (2017). Efektivnist elementiv biologizaciyi $v$ tehnologiyi viroshuvannya ozimoyi pshenici $v$ umovah Pivdennogo Stepu Ukrayini. Thesis of Doctoral Dissertation. Harkiv (in Ukrainian).

Stankevych, S.V., Vasylieva, Yu.V. \& Golovan, L.V. (2019). Chronicle of insect pests massive reproduction. Ukrainian Journal of Ecology, 9 (1), 262-274.

Stankevych S.V., Yevtushenko M.D. \& Zabrodina I.V. (2019). The significance of scientific school of V.V. Dokuchaiev Kharkiv National Agrarian University in development agricultural entomology in the XIX-XXI centuries. Ukrainian Journal of Ecology, 9 (2), $156-169$.

Storchous I. (2013). Protruyuvannya nasinnya - osnovnij zahid dlya kontrolyu hvorob. Propoziciya, 9, 78-81. (in Ukrainian).

Strona I.G. (1984). Doposevnaya i predposevnaya obrabotka semyan selskohozyajstvennyh kultur. pp. 5-16. In Teoriya i praktika predposevnoj obrabotki semyan. Kiev (in Russian).

Sudenko V.Yu. (2016). Posivni yakosti ta vrozhajnist nasinnya pshenici m'yakoyi yaroyi zalezhno vid peredposivnoyi obrobki protrujnikami ta mikrodobrivami. Mironivskij visnik, 3, 160-166. (in Ukrainian).

Tehnologiya mikrohvilovoyi obrobki nasinnya silskogospodarskih kultur: metodichni rekomendaciyi (2003). Kyiv: Agrarna nauka (in Ukrainian).

Timoshenko O.P. (2009). Vpliv peredposivnoyi obrobki mikrohvilyami ta diazofitom nasinnya yaroyi pshenici na urazhennya korenevimi gnilyami ta urozhajnist kulturi. Mikrovolnovye tehnologii v narodnom hozyajstve, $7 / 8,78-81$. (in Ukrainian).

Tuchnyj V.P. (2007). Tehnologiya zavtrashnego polya. Mikrovolnovye tehnologii v narodnom hozyajstve, 6, 9-15. (in Russian).

Tuchnyj V.P., Karmazin Yu.A., Levchenko Ye.A. (2007). Proryv s pomoshyu novoj tehnologi. Hranenie i pererabotka zerna, 4 (94), 11-13. (in Russian).

Tuchnyj V.P., Karmazin A.I., Dzigovskij Yu.A. (2012). Tehnologiya, kotoruyu zhdut agrarii. Hranenie i pererabotka zerna, 1(151),. 21-24. (in Russian).

Turenko V.P., Bilyk M.O. \& Zhukova L.V. (2019). Pathogens of spring barley on abiotic factors in the eastern forest - steppe of Ukraine. Ukrainian Journal of Ecology, 9 (2), 179-188.

Velskij A.I., Plavinskaya A.N. (2003). Magnitno-lazernaya tehnologiya v rastenievodstve. Zernovoe hozyajstvo, 1, 8. (in Russian).

Vladykin I.R. (1999). Povyshenie effektivnosti predposevnoj obrabotki semyan ovoshnyh kultur ultrafioletovym izlucheniem. Thesis of Doctoral Dissertation. Moscow (in Russian).

Voloshina N.M. (2007). Efektivnist biopreparativ novogo pokolinnya dlya zahistu polovih kultur. Proceed. Conf. ["Suchasni intensivni tehnologiyi v roslinnictvi v umovah pivnichnogo Stepu Ukrayini"]. Kirovograd (in Ukrainian).

Yevtushenko M. D., Maryutin F. M. (2001). Pesticidi i tehnologichni zasobi yih zastosuvannya. Harkiv (in Ukrainian).

Zazimko M.I. (1996). Nuzhno li protravlivanie semyan. Zashita i karantin rastenij, 10, 6-9. (in Russian).

Zhukova L.V., Stankevych S.V., Turenko V.P. (2019). Root rots of spring barley, their harmfulness and the basic effective protection measures. Ukrainian Journal of Ecology, 9 (2), 232-238.

\section{Citation:}

Bezpal'ko, V.V., Zhukova, L.V., Stankevych, S.V., Ogurtsov, Yu.H., Klymenko, I.I., Hutians'kyi, R.A., Fesenko, A.M., Turenko, V.P., Zabrodina, I.V., Bondarenko, S.V., Batova, O.M., Golovan, L.V., Klymenko, I.V., Poedinceva, A.A., Melenti, V.O. (2019). Ecologically safe methods for presowing treatment of cereal seeds. Ukrainian Journal of Ecology, 9(3), 189-197.

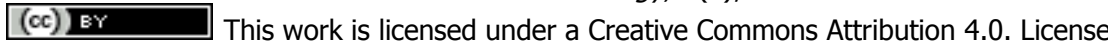

